\title{
ANALISIS FAKTOR-FAKTOR KETAHANAN KELUARGA DI KAMPUNG KB RW 18 KELURAHAN KADIPIRO KOTA SURAKARTA
}

\section{Analysis of Family Resilience Factors in Kampung KB RW 18, Kadipiro Village, Surakarta City}

\author{
Mujahidatul Musfiroh, Sri Mulyani, Erindra Budi C, Angesti Nugraheni, Ika \\ Sumiyarsi
}

Prodi Kebidanan Program Sarjana Terapan FK UNS

email : miedhamus@gmail.com,

\begin{abstract}
ABSTRAK
Latar Belakang: Ketahanan keluarga sangat diperlukan oleh keluarga dalam upaya menghadapi permasalahan-permasalahan sosial di masyarakat. Ketahanan keluarga merupakan gambaran kemampuan keluarga dalam memenuhi segala kebutuhan keluarga yang berkaitan dengan kebutuhan dasar. Penelitian ini bertujuan untuk mengkaji faktor ketahanan keluarga di Kampung KB RW 18 Kelurahan Kadipiro Kota Surakarta.

Metode: Penelitian ini merupakan penelitian observasional analitik. Sampel dalam penelitian ini yaitu 86 responden yang didapat dengan menggunakan teknik cluster random sampling. Sampel ditentukan dengan mengambil keluarga yang tinggal di rumah dengan teknik acak berdasarkan lokasi tempat tinggal. Pengumpulan data penelitian menggunakan instrumen penelitian yaitu kuesioner.

Hasil: Hasil penelitian menunjukan bahwa responden memiliki ketahanan keluarga dengan kriteria baik. Data penelitian menunjukan bahwa seluruh responden (100\%) memiliki pengetahuan baik tentang ketahanan keluarga. Dimensi ketahanan keluarga yang ada pada responden yaitu ketahanan legalitas dan keutuhan keluarga (100\%), ketahanan fisik (80\%), ketahanan ekonomi (90\%), ketahanan sosial psikologi (100\%), dan ketahanan sosial budaya (80\%).

Kesimpulan: Penelitian menunjukan bahwa responden memiliki ketahanan keluarga yang baik, meliputi ketahanan legalitas dan keutuhan keluarga, ketahanan fisik, ketahanan ekonomi, ketahanan sosial psikologi, ketahanan sosial budaya.
\end{abstract}

Kata Kunci : Ketahanan Keluarga, Keluarga, Kampung KB 


\section{ABSTRACT}

Background: Family resilience is needed by the family in an effort to deal with social problems in the community. Family resilience is an illustration of the family's ability to meet all family needs related to basic needs. This study aims to examine the family resilience factor in KB RW 18 Village, Kadipiro Village, Surakarta City.

Method: This study is an analytic observational study. The sample in this study was 86 respondents obtained by using simple random sampling technique. The sample is determined by taking a family living at home with a random technique based on the location of residence. Data collection research uses research instruments, namely questionnaires.

Results: The results showed that respondents had family resilience with good criteria. Research data shows that all respondents (100\%) have good knowledge about family resilience. The dimensions of family resilience that exist in respondents are legality and family integrity (100\%), physical endurance (80\%), economic resilience (90\%), psychological social security (100\%), socio-cultural resilience (80\%).

Conclusion: The conclusions of the study showed that respondents had good family resilience, including resistance to legality and family integrity, physical resilience, economic resilience, social security of psychology, socio-cultural resilience.

Keywords: Family Resilience, Family, Kampung KB

\begin{tabular}{l}
\hline \multicolumn{3}{c}{ LATAR BELAKANG } \\
\hline Ketahanan keluarga merupakan alat \\
untuk mengukur pencapaian keluarga \\
dalam melaksanakan peran, fungsi dan \\
tanggung jawabnya dalam mewujudkan \\
kesejahteraan anggota. Tingkat ketahanan \\
keluarga ditentukan oleh perilaku \\
individu dan masyarakat. Individu dan \\
keluarga yang memiliki pengetahuan dan \\
pemahaman tentang ketahanan keluarga \\
yang baik, akan mampu bertahan dengan \\
perubahan struktur, fungsi dan peranan \\
keluarga yang berubah sesuai \\
perkembangan teknologi informasi dan \\
komunikasi. Individu dan keluarga yang \\
mampu bertahan dengan perubahan \\
lingkungan, berpotensi memiliki \\
ketahanan keluarga yang kuat ${ }^{[1]}$. \\
Ketahanan keluarga menjadi tolak \\
ukur kemampuan keluarga dalam \\
memenuhi kebutuhan dasar dan \\
kemampuan keluarga untuk melakukan \\
kegiatan yang produktif. Ketahanan \\
keluarga bertujuan untuk meningkatkan \\
kesejahteraan dan kemandirian keluarga ${ }^{[2]}$. \\
Ketahanan keluarga yang baik didukung \\
oleh sumber daya non fisik yang baik, \\
mekanisme penanggulangan masalah yang
\end{tabular}

baik oleh keluarga, dan kemampuan keluarga dalam memenuhi kebutuhan sosial keluarga. Ketahanan keluarga menunjukan kondisi keluarga yang memiliki keuletan dan letangguhan serta mengandung kemampuan fisik materiil untuk mencapai kehidupan yang mandri dan mampu mengembangkan diri dan keluarga untuk hidup harmonis dalam meningkatkan kesejahteraan, kebahagiaan lahir dan batin. Observasi terhadap pola ketahanan keluarga pada masyarakat diharapkan dapat menentukan tindakan, kebijakan, dan program untuk meningkatkan kemampuan keluarga dalam memenuhi kebutuhan dasar dan kemampuan keluarga untuk melakukan kegiatan yang produktif, sehingga kualitas hidup manusia dapat ditingkatkan ${ }^{[3]}$.

Penelitian ini dilakukan untuk mengkaji faktor ketahanan sehingga upaya penyempurnaan pola ketahanan keluarga pada masyarakat dapat tercapai. Pola ketahanan keluarga menunjukan kemampuan keluarga dalam memenuhi kebutuhan dasar dan kemampuan keluarga untuk melakukan kegiatan yang produktif sehingga dapat mempengaruhi 
peningkatan kualitas hidup manusia.

\section{SUBJEK DAN METODE}

Metode penelitian ini yaitu observasional analitik dengan pendekatan cross sectional sehingga variabel bebas dan variable terikat diamati dalam satu waktu. Teknik pengambilan sampel dalam penelitian ini yaitu cluster random sampling. Sampel diambil dari populasi keluarga yang tinggal di wilayah RW 18 Kelurahan Kadipiro Kota Surakarta. Jumlah sampel dalam penelitian ini yaitu 86 responden yang memenuhi kriteria retriksi (berada di rumah saat pengumpulan data, tinggal bersama keluarga dan bersedia menjadi responden). Pengamatan penelitian ini meliputi pola ketahanan keluarga di Kampung KB RW 18 Kelurahan Kadipiro Kecamatan Banjarsari Kota Surakarta. Pola ketahanan keluarga yang diamati meliputi landasan legalitas, keutuhan keluarga, kemitraan gender, kecukupan pangan dan gizi, kesehatan keluarga, ketersediaan tempat atau lokasi tetap untuk tidur, tempat tinggal keluarga, pendapatan keluarga, pembiayaan pendidikan anak, jaminan keuangan keluarga, keharmonisan keluarga, kepatuhan terhadap hukum, kepedulian sosial, keeratan sosial, dan ketaatan beragama. Analisis hasil penelitian dilakukan dengan bantuan program excel dan SPSS.

\section{HASIL}

Hasil penelitian menunjukan bahwa pengetahuan responden tentang ketahanan keluarga dalam kategori baik. Seluruh responden (100\%) memahami mengenai definisi ketahanan keluarga, sikap dan perilaku anggota keluarga yang memperkuat ketahanan keluarga. Ketahanan keluarga yang dilakukan oleh responden antara lain: sikap saling melayani antar anggota keluarga, menjaga keutuhan perkawinan, saling menyayangi antar anggota keluarga, memberikan peringatan atau nasihat kepada anaggota keluarga yang berbuat salah, tidak memaksakan keinginan terhadap anggota keluarga, meluangkan waktu untuk berkumpul dengan keluarga, memiliki surat nikah dan akta kelahiran, suami istri merencanakan jumlah anak secara bersama, suami istri merencanakan alat kontrasepsi yang akan dipakai, keluarga menyediakan makanan dengan gizi seimbang, keluarga memiliki tempat tinggal yang layak sesuai kriteria rumah sehat, keluarga memiliki pendapat yang cukup untuk memenuhi kebutuhan keluarga, semua anak usia sekolah mendapatkan pendidikan formal di sekolah, keluarga memiliki simpanan atau tabungan, keluarga memiliki jaminan kesehatan, keluarga menghargai, menghormati dan membantu anggota keluarga lain dan tetangga, keluarga mengikuti kegiatan keagamaan dan kemasyarakatan serta hidup rukun dalam keluarga dan masyarakat.

Hasil penelitian menunjukan bahwa gambaran pola ketahanan keluarga meliputi ketahanan legalitas dan keutuhan keluarga telah $100 \%$ dilakukan oleh responden, ketahanan fisik telah $80 \%$ dilakukan oleh responden, ketahanan ekonomi telah $90 \%$ dilakukan oleh responden, ketahanan sosial psikologi telah $100 \%$ dilakukan oleh responden, dan ketahanan sosial budaya telah $80 \%$ dilakukan oleh responden. Ketahanan legalitas dan keutuhan keluarga yang dilakukan responden antara lain : orang tua menyediakan waktu untuk berkumpul bersama anak, seluruh anggota keluarga telah memiliki akte kelahiran, keluarga memiliki surat nikah, suami dan istri bersama untuk menentukan alat kontrasepsi dan menentukan jumlah anak. Ketahanan fisik yang dilakukan oleh keluarga antara lain : keluarga menyediakan makanan dengan menu seimbang, setiap anggota keluarga mendapatkan tempat tidur yang layak. Ketahanan fisik keluarga yang belum optimal dilakukan oleh keluarga, yaitu penyediaan menu seimbang oleh 
keluarga yang hanya dilakukan oleh 9 responden (10\%). Namun tidak optimalnya penyediaan menu seimbang oleh keluarga tidak memberikan dampak penurunan ketahanan fisik keluarga, karena dalam keluarga tidak terdapat anggota keluarga yang mengalami gangguan gizi dan tidak ada anggota keluarga yang menderita sakit. Ketahanan ekonomiyang dilakukan oleh keluarga antara lain : keluarga sudah memiliki tempat tinggal, keluarga memiliki pendapatan yang cukup untuk memenuhi kebutuhan keluarga, seluruh anggota keluarga usia sekolah masih bersekolah, keluarga memiliki tabungan, dan keluarga memiliki jaminan kesehatan. Ketahanan ekonomi keluarga responden belum optimal, karena terdapat $12(10 \%)$ belum memiliki tempat tinggal sendiri, $14(20 \%)$ tidak memiliki pendapatan yang cukup untuk memenuhi kebutuhan keluarga dan 23 (30\%) tidak memiliki tabungan atau simpanan berupa uang. Ketahanan sosial psikologi yang dilakukan responden antara lain: menjaga kerukunan dalam rumah tangga, mencegah terjadinya kekerasan dalam rumah tangga, serta tidak ada anggota keluarga yang bertindak melanggar hukum. Ketahanan sosial budaya yang dilakukan oleh responden antara lain : keikutsertaan keluarga merawat lansia, keikutsertaan keluarga dalam kegiatan sosial keagamaan dan sosial kemasyarakatan, keluarga saling hidup rukun dan saling membantu dengan tetangga. Ketahanan sosial budaya yang belum optimal dilakukan oleh responden, yaitu keikutsertaan keluarga dalam merawat lansia. Hal ini disebabkan keluarga tidak tinggal serumah dengan lansia, sehingga keikutsertaan keluarga dalam merawat lansia rendah (20\%).

\begin{tabular}{l}
\hline \multicolumn{3}{c}{ PEMBAHASAN } \\
\hline Responden penelitian memiliki \\
pengetahuan ketahanan keluarga dengan \\
kategori baik sebanyak 86 responden \\
$(100 \%)$. Responden telah memahami
\end{tabular}

mengenai definisi ketahanan keluarga, sikap dan perilaku anggota keluarga yang memperkuat ketahanan keluarga. Pengetahuan responden didukung dengan data hasil wawancara bahwa 40 responden $(47 \%)$ telah mendapatkan informasi mengenai ketahanan keluarga. Ketahanan keluarga berhubungan dengan dengan ketersediaan akses dan sumber informasi bagi keluarga, tingkat pendidikan orang tua dalam keluarga, pendapatan keluarga, usia anggota keluarga, dan aset yang dimiliki keluarga $^{[4]}$.

Sebuah keluarga akan memiliki ketahanan jika keluarga tersebut dapat berperan secara optimal dalam mewujudkan seluruh potensi yang dimiliki keluarga. Ketahanan keluarga menggambarkan kecukupan dan kesinambungan akses terhadap pendapatan dan sumber daya untuk memenuhi kebutuhan dasar termasuk kecukupan akses terhadap pangan, air bersih, pelayanan kesehatan, kesempatan pendidikan, perumahan, waktu untuk berpartisipasi di masyarakat, dan integritas sosial $^{[1]}$. Ketahanan keluarga juga mencakup kemampuan keluarga untuk mengelola sumber daya dan masalah untuk mencapai kesejahteraan ${ }^{[5]}$. Ketahanan keluarga merupakan ketangguhan keluarga untuk hidup mandiri dan kemampuan keluarga untuk melindungi keluarga dari berbagai ancaman. Ketahanan keluarga yang dilakukan oleh responden sesuai dengan 5 (lima) indikasi tingkat ketahanan keluarga. Lima indikasi yang menggambarkan tingkat ketahanan keluarga yaitu sikap saling melayani sebagai tanda kemuliaan, keakraban antara suami dan istri menuju kualitas perkawinan yang baik, orangtua yang mengajar dan melatih anak-anaknya dengan berbagai tantangan kreatif, pelatihan yang konsisten, dan mengembangkan ketrampilan, suami dan istri yang memimpin seluruh anggota keluarga dengan penuh kasih sayang, 
anak-anak yang mentaati dan menghormati orangtua $^{[1]}$. Konsep ketahanan dan kesejahteraan keluarga mencakup, yaitu : landasan legalitas dan keutuhan keluarga, ketahanan fisik, ketahanan ekonomi, ketahanan sosial psikologi, dan ketahanan sosial budaya ${ }^{[6]}$ Pola ketahanan keluarga responden meliputi ketahanan legalitas dan keutuhan keluarga, ketahanan fisik, ketahanan ekonomi, ketahanan sosial psikologi, dan ketahanan sosial budaya. Ketahanan keluarga meliputi ketahanan fisik keluarga, ketahanan sosial keluarga, dan ketahanan psikologi keluarga ${ }^{[4]}$. Ketahanan fisik keluarga yaitu ketahanan keluarga dalam pemenuhan sumber daya fisik, mengatasi dan beradaptasi dengan masalah yang berkaitan dengan ekonomi dan kegiatan rumah tangga yang bersifat fisik, serta pemenuhan kebutuhan dasar keluarga. Ketahanan sosial keluarga yaitu kekuatan keluarga dalam penerapan nilai agama, pemeliharaan ikatan dan komitmen, komunikasi efektif, pembagian peran dan penerimaan peran, penetapan tujuan, serta dorongan untuk maju yang akan menjadi kekuatan dalam menghadapi masalah keluarga (termasuk masalah perkawinan) dan memiliki hubungan sosial yang sehat. Ketahanan psikologi keluarga yaitu kemampuan anggota keluarga untuk mengelola emosinya, sehingga menghasilkan konsep diri yang positif. Ketahanan psikologi keluarga meliputi kemampuan mengelola emosi dan konsep diri yang baik.

Ketahanan keluarga merupakan stabilisasi keluarga yang adaptif dan pengaturan pada sistem keluarga setelah gangguan pada keluarga yang disebabkan oleh kesulitan dan masalah. Ketahanan keluarga juga dapat diartikan sebagai proses pertahanan keluarga terhadap fungsi keluarga setelah menghadapi kesulitan atau masalah ${ }^{(7)}$. Ketahanan keluarga adalah proses pengaturan dalam sistem dinamis, pembentukan keseimbangan dalam suatu sistem karena gangguan dan kesulitan yang dimiliki oleh keluarga ${ }^{[8]}$. Ketahanan keluarga yang baik dan optimal dapat menjamin keberlangsungan hidup keluarga dalam beradaptasi dan bertahan terhadap berbagai masalah dan kesulitan yang dihadapi keluarga.

Pola ketahanan keluarga yang dilakukan oleh responden merupakan bentuk kemampuan keluarga untuk menjamin keberlangsungan hidup keluarga atau ketahanan keluarga dan mencapai kesejahteraan keluarga. Keberlangsuangan hidup keluarga atau ketahanan keluarga merupakan kemampuan keluarga dalam mengelola sumber daya yang dimiliki keluarga serta menanggulangi masalah yang dihadapai untuk dapat memenuhi kebutuhan fisik dan psikososial keluarga. Sedang kesejahteraan keluarga merupakan keadaan akhir yang dituju melalui proses pengelolaan input dan penanggulangan masalah $^{[9]}$. Pola ketahanan keluarga responden meliputi aspek fisik dan non fisik (ketahanan legalitas dan keutuhan keluarga, ketahanan ekonomi, ketahanan sosial psikologi dan ketahanan sosial budaya). Pola ketahanan keluarga dapat dioptimalkan dengan pembangunan ketahanan keluarga. Pembangunan ketahanan keluarga dilakukan melalui dua jalur, yaitu pembangunan ketahanan fisik dan pembangunan ketahanan non fisik. Pembangunan ketahanan fisik, antara lain : bantuan, pemberian bantuan modal, askeskin, raskin untuk keluarga pra sejahtera dan keluarga sejahtera I. Pembangunan ketahanan non fisik, antara lain : meningkatkan kualitas pendidikan, kualitas kesehatan kepribadian, keagamaan serta pemahaman terhadap fungsi-fungsi keluarga berjalan sebagaimana mestinya ${ }^{[10]}$. Pembangunan ketahanan keluarga sesuai dengan pola ketahanan keluarga responden yang terdiri dari ketahanan fisik dan fisik.

\begin{tabular}{lcr}
\hline \multicolumn{3}{c}{ SIMPULAN } \\
\hline Ketahanan & keluarga & merupakan \\
kemampuan & keluarga & untuk
\end{tabular}


menggunakan sumber daya yang dimiliki keluarga dalam mencapai kemandirian dan kesejahteraan keluarga. Pola ketahanan keluarga yang baik dan optimal menjadikan keluarga lebih siap dan kuat dalam menyelesaikan masalah dan kesulitan yang dihadapi keluarga.

\section{SARAN}

Penelitian selanjutnya perlu melakukan penelitian terhadap faktor internal dan eksternal yang mempengaruhi ketahanan keluarga, seperti : produktivitas keluarga, jumlah anggota keluarga, variasi usia anggota keluarga, kondisi sosial kemasyarakatan dan partisipasi masyarakat.

\section{DAFTAR PUSTAKA}

1. Cahyaningtyas A, Tenrisana AA, Triana D, Prastiwi DA, Nurcahyo EH, Jamilah, Aminiah N T VD. Pembangunan Ketahanan Keluarga 2016. Utami DRWWU, Krismawati PL, Karmaji, Lestari P, Aryanti D, Susilowati A, Fitri S, Skriptandono, Anugerah DR LS, editors. Kementerian Pemberdayaan PErempuan dan Perlindungan Anak. Jakarta: CV. Lintas Khatulistiwa; 2016. 39 p.

2. Prayitno US, Retnaningsih $\mathrm{H}$, Prihatin RB, Prihatin RB, Mulyadi $\mathrm{M}$, Winurini $\mathrm{S}$, et al. Ketahanan Keluarga untuk Masa Depan Bangsa. Sulistyaningsih RE, editor. Jakarta: PT Dian Rakyat; 2016.

3. Indonesia PR. UU RI No 52 Tahun 2009 tentang Perkembangan Kependudukan dan Pembangunan Keluarga. 52 Tahun 2009 Jakarta; 2009 p. 2.

4. Sunarti E F. Kajian Modal Sosial, Dukungan Sosial, dan Ketahanan Keluarga Nelayan di Daerah Rawan Bencana. J Ilmu Kel Konsum [Internet]. 2010;3(2):93-100. Available from: http://journal.ipb.ac.id/index.php/jikk /article/view/5188/11390
5. Sunarti E. Studi Ketahanan Keluarga dan Ukurannya: Telaah Kasus Pengaruhnya terhadap Kualitas Kehamilan. Institut Pertanian Bogor; 2001.

6. Menteri Negara Pemberdayaan Perempuan dan Perlindungan Anak Republik Indonesia. Peraturan Menteri Negara Pemberdayaan Perempuan dan PErlindungan Anak Republik Indonesia. Nomor 6 Tahun 2013 Jakarta; 2013 p. 1-39.

7. Patterson JM. Integrating Family Resilience and Family Stress Theory. J Marriage Fam. 2002;64(2):349-60.

8. Macphee D, Lunkenheimer E, Riggs $\mathrm{N}$. Resilience as Regulation of Developmental and Family Processes. Fam Relat. 2015;64(1):153-75.

9. Sunarti E, Syarief H, Megawangi R, Hardinsyah, Saefuddin A H. Measurement of Family Strength. Media Gizi dan Kel [Internet]. 2003;27(1):1-11. Available from: http://journal.ipb.ac.id/index.php/me diagizi/article/view/2403/1407

10. Purwandiyah H. Implementasi Program Keluarga Berencana Dalam Pembangunan Keluarga Sejahtera (Studi di Kec. Telen Kabupaten Kutai Timur, Propinsi Kalimantan Timur). J Paradig [Internet]. 2013;2(1):127-32. Available from: ejournals.unmul.ac.id/index.php/JPara digma/article/download/348/309 